\title{
Excellence-Driven Policies and Initiatives in the Context of Bologna Process: Rationale, Design, Implementation and Outcomes
}

\author{
Isak Froumin and Mikhail Lisyutkin
}

\section{Introduction}

Bologna Process is rightly seen as one of the most significant policy initiatives in the field of higher education. A comprehensive and transformative nature of this large-scale policy has resulted in a growing attention to universities' external accountability, to the organization of the quality and to the efficiency of the resources use (Sadlak 2011). Excellence-driven policies represent a more riffle approach to enhance higher education. The set of the governments' actions aimed at the improvement of national higher education system global competitiveness, most commonly represented by the transformation of existing universities into the so-called world-class universities (Salmi 2009) or establishing new world-class universities has been generally considered as the excellence-driven policy.

Started in a few countries and became a frequent practice when world universities ranking has joined the range of the top issues in higher education policy agenda, the excellence-driven policies became prior considerations in many countries. Consequently, "more and more countries are joining the race of building up world-class universities by establishing special initiatives" (Sadlak and Liu 2009 , p. 16). These initiatives changed the focus of higher education policy discourse from the overall quality maintenance to supporting the limited number of universities aimed to achieve world-class status or global excellence (Altbach and Salmi 2011). At the same time, they affected the whole higher education systems by

I. Froumin $(\bowtie) \cdot$ M. Lisyutkin

National Research University "Higher School of Economics", Moscow, Russia

e-mail: ifroumin@hse.ru

M. Lisyutkin

e-mail: mlisyutkin@hse.ru

(C) The Author(s) 2015

A. Curaj et al. (eds.), The European Higher Education Area,

DOI 10.1007/978-3-319-20877-0_17 
stimulating the competition between universities, by changing the financing patterns and thus promoting the most desirable model of Research University (Mohrman et al. 2008).

Practically, all modern higher education policies mentioned above somehow interact with Bologna process. They influence each other. The interaction between Bologna Process and excellence-driven policies and initiatives is most interesting, but controversial. Indeed, the excellence orientation is striving for the highest level of quality and performance, but does not serve as a common denominator in normative hierarchies of academic quality within the Bologna Process.

The objective of the research ${ }^{1}$ represented in the paper is to look at the design and implementation of the excellence-driven policies in different countries in the context of the whole system development, and particularly in the context of the Bologna Process. Such policies could be considered as a sign of the more active role of the state in higher education development by designing and implementing new types of institutions and higher education programs. It can be argued that this is a new stage of the introduction of New Public Management (NPM) in higher education (Bleiklie 1988).

The analysis starts with the rationale of these initiatives in the context of national higher education policies within the theoretical framework that puts the state in the centre of higher education policy. The next section is devoted to the design of such initiatives. Various excellence-driven initiatives, their common and unique features are analyzed to develop general design of excellence-driven policy. The implementation mechanisms and impact of the implementation of these policies is the focus of the next section. In the concluding section, the question of the relationships between Bologna Process and excellence initiatives in the context of the national higher education policies is discussed.

\section{Rationale of Excellence-Driven Policies and Initiatives}

The expression "excellence initiative" frequently used in the text was borrowed from the German policy in higher education. It means an initiative aimed to promote top-level research and to improve the quality of universities and research institutions in general, thus making Germany a more attractive research location, making it more internationally competitive (Kehm 2006). Making this definition more theoretical and universal, excellence-driven initiatives and policies can be described as a "large injection of funding by a national government aimed at

\footnotetext{
${ }^{1}$ J. Salmi's description of different excellence initiatives commissioned by the Russian Ministry of Education and Science used in the analysis. Part of this analysis was published in Russian (Salmi and Froumin 2013). Various national reports and regulatory documents related to the excellence initiatives are also used as a basis for the study. Another important source of the data and ideas was the set of interviews conducted in 2012-2014 with policy makers and senior universities administrators from seven countries.
} 
financing the development of world-class universities in an accelerated fashion. These programs are usually very selective in terms of the number of beneficiary universities and the research focus of the upgrading efforts" (Salmi and Froumin 2013, p. 31).

There are different approaches to establish a group of globally competitive universities in different countries. The paper examines these approaches by looking at the excellence-driven policies and initiatives in more than 20 countries, including countries from the European Higher Education Area such as Germany, Denmark, Russia, and Norway, as well as the countries in other regions. Essentially, there are two main approaches to solve the problem of establishing a segment of globally competitive universities: to transform existing universities and to establish new ones. Certain countries, such as Hong Kong, Kazakhstan, Saudi Arabia and Singapore, have established new universities as greenfield projects, while the majority of countries concentrated on the modernization of the existing universities (Salmi 2009).

Table 1 shows the spread of the excellence-initiatives throughout the world. It should be noticed that Asian and American cases are included into the list; also they could help understand the relationships between the excellence initiatives and whole system-level policies.

This list is not complete because there are plenty of projects on individual universities' creation or development which deeply vary from the above listed initiatives and could come under separate analysis. Such projects are the Masdar University in Abu-Dhabi, the Nazarbaev University in Kazakhstan, Skolkovo Institute of Science and Technologies and Innopolis University in Russia, Paris-Saclay University in France, the KAUST in Saudi Arabia. Some relatively small scale government projects on improving research and graduate education in selected universities with the support of the leading world-class universities, such as MIT-Portugal program or Singapore-MIT Alliance for Research and Technology, are also not in the list.

We do not consider in this paper some projects of forming "strong" universities through a merger facilitated by the government, as Aalto University in Finland, the Beijing Medical University and Beijing University in China, the Victoria University of Manchester and the University of Manchester Institute of Science and Technology. Despite being incomplete, the table clearly shows that the last 15 years are the period when excellence policies gained wide distribution. Why did this happen? Which functions are charged to excellence-driven policies and initiatives?

A range of interviews were conducted to look at the roots of different higher education policy initiatives. Interviews have shown that many of them grew from the "bottom" of the system, from institutional level. Governments and society often embrace and convert them into system-wide policies.

On the other hand, excellence initiatives almost always come from the top, often from the very high levels of the government. This requires looking at this issue through the theoretical lens of the relationship between the state and higher education development. Such theoretical framework was suggested by Carnoy et al. (2013) in the recent book on higher education development in BRIC countries. It was suggested that modern state takes a more and more central role in higher 
Table 1 The list of national excellence-driven policies and initiatives

\begin{tabular}{|c|c|c|c|}
\hline Year & Country & Name of the policy & Allocated funds \\
\hline \multirow[t]{2}{*}{2002} & Japan & $\begin{array}{l}\text { Top-30 program (centres of } \\
\text { excellence for } 21 \text { st century } \\
\text { plan) }\end{array}$ & US\$484 million \\
\hline & China & 211 project & US\$3 billion \\
\hline \multirow[t]{2}{*}{2003} & Australia & ARC centres of excellence & US $\$ 255.9$ million yearly \\
\hline & Norway & Centres of excellence scheme & $\begin{array}{l}\text { US } \$ 1.5-3 \text { million per CoE for a } \\
\text { maximum of ten years }\end{array}$ \\
\hline \multirow[t]{2}{*}{2004} & China & 985 project & US $\$ 6.6$ billion (Phase II) \\
\hline & $\begin{array}{l}\text { South } \\
\text { Korea } \\
\end{array}$ & $\begin{array}{l}\text { New university for regional } \\
\text { innovation project }\end{array}$ & US $\$ 1$ billion \\
\hline \multirow[t]{3}{*}{2005} & \begin{tabular}{|l|} 
Russian \\
Federation \\
\end{tabular} & Federal university program & US\$411 million \\
\hline & Taiwan & $\begin{array}{l}\text { 1. Developing a first-class } \\
\text { university and top research } \\
\text { centres }\end{array}$ & 1. US $\$ 1.7$ billion (Phase I) \\
\hline & & $\begin{array}{l}\text { 2. Teaching excellence } \\
\text { development program }\end{array}$ & 2. US\$666 million \\
\hline \multirow[t]{5}{*}{2006} & Germany & Excellence initiative & US $\$ 2.35$ billion (Phase I, Phase II) \\
\hline & & 1. Brain Korea 21 program & 1. US $\$ 2.1$ billion (Phase II) \\
\hline & $\begin{array}{l}\text { South } \\
\text { Korea }\end{array}$ & $\begin{array}{l}\text { 2. BK21-MS global internship } \\
\text { program }\end{array}$ & 2. US\$1 million \\
\hline & \begin{tabular}{|l|} 
Russian \\
Federation
\end{tabular} & Innovative university program & US\$920 million \\
\hline & Singapore & $\begin{array}{l}\text { Campus for research excellence } \\
\text { and technological enterprise }\end{array}$ & US\$335 million \\
\hline \multirow[t]{4}{*}{2007} & Japan & $\begin{array}{l}\text { 1. Global centres of excellence } \\
\text { program }\end{array}$ & $\begin{array}{l}\text { 1. US\$640,000-6.4 million per center } \\
\text { per year }\end{array}$ \\
\hline & & $\begin{array}{l}\text { 2. World premier international } \\
\text { research centre initiative }\end{array}$ & 2. US $\$ 108$ million per year \\
\hline & Singapore & $\begin{array}{l}\text { 1. Research centres of } \\
\text { excellence }\end{array}$ & 1. US $\$ 603.3$ million \\
\hline & & $\begin{array}{l}\text { 2. Competitive research } \\
\text { program funding scheme }\end{array}$ & $\begin{array}{l}\text { 2. 4-8 US\$ million per program over } \\
\text { 3-5 years }\end{array}$ \\
\hline \multirow[t]{8}{*}{2008} & Canada & $\begin{array}{l}\text { Global excellence research } \\
\text { chairs }\end{array}$ & $\begin{array}{l}\text { Each } 29 \text { chair-holders and their research } \\
\text { teams receive up to US } \$ 10 \text { million over } \\
7 \text { years }\end{array}$ \\
\hline & China & 211 project (Phase III) & NA \\
\hline & Denmark & $\begin{array}{l}\text { Investment capital for } \\
\text { university research }\end{array}$ & US\$79.3 million \\
\hline & France & Operation campus & US $\$ 6.2$ billion \\
\hline & Malaysia & \multirow{2}{*}{$\begin{array}{l}\text { Accelerated program for } \\
\text { excellence (APEX) }\end{array}$} & \multirow[t]{2}{*}{ NA } \\
\hline & Nigeria & & \\
\hline & & $\begin{array}{l}\text { World-class universities } \\
\text { program }\end{array}$ & NA \\
\hline & $\begin{array}{l}\text { South } \\
\text { Korea }\end{array}$ & $\begin{array}{l}\text { National project towards } \\
\text { building world class } \\
\text { universities }\end{array}$ & US\$720 million \\
\hline
\end{tabular}


Table 1 (continued)

\begin{tabular}{|c|c|c|c|}
\hline Year & Country & Name of the policy & Allocated funds \\
\hline \multirow[t]{3}{*}{2009} & $\begin{array}{l}\text { Russian } \\
\text { Federation }\end{array}$ & $\begin{array}{l}\text { National research university } \\
\text { program }\end{array}$ & US\$1.6 billion \\
\hline & Spain & $\begin{array}{l}\text { International campus of } \\
\text { excellence }\end{array}$ & US\$313.3 million \\
\hline & Thailand & $\begin{array}{l}\text { National research universities } \\
\text { development project }\end{array}$ & US\$380 million \\
\hline \multirow[t]{2}{*}{2010} & Israel & $\begin{array}{l}\text { I-CORE - the Israeli centres for } \\
\text { research excellence }\end{array}$ & US\$360 million \\
\hline & France & Excellence laboratories & US $\$ 1.24$ billion \\
\hline \multirow[t]{6}{*}{2011} & China & 985 project (Phase III) & NA \\
\hline & \multirow[t]{2}{*}{ France } & $\begin{array}{l}\text { 1. Excellence equipment } \\
\text { program }\end{array}$ & 1. US $\$ 1.24$ billion \\
\hline & & 2. Excellence initiative & 2. US\$9.53 billion \\
\hline & \multirow[t]{2}{*}{ Taiwan } & $\begin{array}{l}\text { 1. Moving into top universities } \\
\text { program }\end{array}$ & 1. US\$330 million \\
\hline & & $\begin{array}{l}\text { 2. Teaching excellence program } \\
\text { (second phase) }\end{array}$ & 2. NA \\
\hline & Romania & Higher education reform bill & NA \\
\hline \multirow[t]{5}{*}{2012} & China & 2011 plan (Phase I) & NA \\
\hline & France & $\begin{array}{l}\text { Excellence initiatives for } \\
\text { training }\end{array}$ & US\$185.8 million \\
\hline & Germany & Excellence initiative (Phase II) & US\$2.97 billion \\
\hline & India & $\begin{array}{l}\text { Universities of research and } \\
\text { innovation bill }\end{array}$ & NA \\
\hline & Poland & $\begin{array}{l}\text { Creation of "national centres of } \\
\text { research excellence" (KNOW) }\end{array}$ & US\$90 million \\
\hline 2013 & $\begin{array}{l}\text { Russian } \\
\text { Federation }\end{array}$ & $\begin{array}{l}\text { Global competitiveness } \\
\text { enhancement of Russian } \\
\text { universities ("5-100") }\end{array}$ & $\begin{array}{l}\text { US } \$ 880 \text { million (2013-2017) (entire } \\
\text { project will be implemented until 2020) }\end{array}$ \\
\hline \multirow[t]{3}{*}{2014} & Africa & $\begin{array}{l}\text { Africa higher education centres } \\
\text { of excellence }\end{array}$ & $\$ 290.8$ million (The World Bank) \\
\hline & Japan & Top global university project & $\begin{array}{l}\$ 65 \text { million (the project will be } \\
\text { implemented for } 10 \text { years) }\end{array}$ \\
\hline & Canada & $\begin{array}{l}\text { Science technology and } \\
\text { innovation strategy }\end{array}$ & $\begin{array}{l}\$ 1.3 \text { billion (the project will be } \\
\text { implemented for } 10 \text { years) }\end{array}$ \\
\hline
\end{tabular}

Source Salmi and Froumin (2013) adjusted

education development because the expansion of higher education is the key for the development of modern economy, and because a state seeks the legitimation by expanding the higher education and showing its global quality, global competitiveness. This framework refers to John Meyer's on how and why states gain their legitimacy (Boli et al. 1985; Meyer and Rowan 1977). It is argued that under the globalization process governments need not only internal, but also global legitimacy to be competitive and to act as an equal partner in international collaboration. 
Within this framework, the main reason for the government intervention in the form of excellence driven policies becomes clear. It lies in the fact that the governments are not happy with the slow evolution of the higher education systems. It is understood by the states that universities could play a significant role in the development of globally competitive innovation-based economies or in the global political and cultural competition.

Governments want universities to bring the fruits of the innovation economy as fast as possible. Governments accelerate the changes through the regulatory framework, push universities to compete internationally by offering them additional funding, and direct the universities on what and how they should do.

Some countries, for example, Australia and the United Kingdom, consider their higher education systems not just as innovation-based economy growth drivers, but also as direct economic agents that produce a significant part of the national GDP by selling the educational services, especially to foreign students. For instance, education exports are Australia's fourth largest export, generating $\$ 15$ billion revenues each year, most of which in higher education. Over the past five years, international students have provided Australian universities with $\$ 18.5$ billion (Group of Eight 2014, Australia 2014). For such countries as Australia, the existence of world-class universities makes the whole higher education system more attractive for the international students. This fact indicates that one of the main objectives of the world-class universities is the attraction of international students promoting the whole higher education system globally.

The role of universities in attracting foreign students and best professors as future cadres of innovative economy is indeed an important part of the rationale. Most countries realized that they should be on brain gain rather than on brain drain side. Internationally branded universities could be convenient and efficient channels for such migration of talents (Salmi 2012). Cambridge, ETH Zurich and Imperial College are world-class universities that may serve as examples of such attractors within the European higher education area.

Another important driver of the excellence initiatives is the growing focus on the research as a part of the public policy. Despite the fact that most policy documents describing the excellence initiatives state that such initiatives are aimed at improving the whole higher education system or at least the process of education at selected universities, in reality they create the conditions for the research universities, not the so-called teaching universities, to flourish. As K. Mohrman noted, the excellence initiatives promote a more or less universal model of global research university (Mohrman et al. 2008).

Various governments put the excellence initiatives into broader frameworks of strengthening the research productivity of the universities. They supported not just universities as a whole institution, but separate advanced research centres and individual departments as well. Like Germany or Canada, these countries created a comprehensive "excellence package" that included "excellence measures" of different scale. It helped these countries to involve more universities in such programs and to create favourable environments for them. 
Similarly, the series of the states introduced "excellence initiatives" together with the measures to support excellence and innovations in education. Germany made the development of modern graduate school part of its excellence program. Canada, in its turn, introduced "The Canada Research Chairs" program to support research and innovation development in Canadian universities, and to attract leading scholars and scientists. French government is well-known for its initiatives to establish "poles of competitiveness" as the mechanisms to promote regional economic growth.

Some countries had quite specific additional rationale to introduce the excellence initiatives. Big countries like China, India and Russia, in addition to the reasons which were discussed above, tried to solve the problem of the regional development by establishing world-class universities in regions or macro-regions.

Another rationale to implement excellence-driven policies comes from the countries with the objectives for the development of specific sectors of economy. In this case, the French "poles of competitiveness" included the development of the universities that became the parts of the industrial clusters relevant to such activities as automotive industry, aeronautics, pharmaceuticals, instrumentation, communication equipment and chemistry (Bretones 2011). Abu-Dhabi invested a huge amount of money into the establishment of the Masdar Institute with a clear specialization in sustainable technologies as a part of the Masdar sustainable city project (Lau 2012). Brazil invited MIT to contribute to the development of a small university specialized in aviation. Singapore (having already two excellent universities) decided to create another one, also with MIT support, in the area of design (SUDT-MIT 2014).

The desire to have world-class universities has its roots not just in rational considerations, but also in the symbolic role of such universities. They are increasingly becoming a part of the legitimation of the state, like a football team or the national opera. The expansion of international rankings has made the governments vulnerable in defending their global legitimacy in the area of higher education. Before the universities were compared internationally, governments could hide behind the history of particular universities or could build impressive university campuses to create an impression that the country had great universities.

The rankings made the competition between the states very visible. It should be stressed that the international rankings are playing a more and more important role in such policies. The rankings are most commonly recognized as an indicator of success of excellence-driven policies (Salmi 2009). Moreover, in some cases there is a substitution of concepts when places in the rankings become main goals by themselves, but not the detectors of policy implementation.

This fact shows how the political and broad social and economic objectives of the excellence-driven policies shape the model of the world-class university. Indeed, the research and educational productivity of a particular university could be high even if this university does not have a lot of international students. However, these students are becoming a symbol of a global recognition and strong economic impact of such universities. 
The emergence of the excellence-driven policies also reflects the growing influence of the New Public Management in higher education (Bleiklie 1988; Ferlie et al. 1996; Hood 1991; Stech 2011), such as performance based funding, accountability, external quality control, or business-like managerial practices. One of the objectives of new public management in higher education is the strengthening of the competition between the universities. Such competition leads to greater differentiation in higher education system (Froumin et al. 2014) and creation of segments of losers and winners. It should be admitted that the analysis of the histories of some excellence initiatives has shown that the government pressure was not fully coercive - it was supported by the winners - the leading universities that considered the excellence initiative as the opportunity for them.

Bologna process had also created favourable conditions for the excellence-driven policies. This process moved from very national (local) and peculiar higher education systems into more comparable and even similar mechanisms. Bologna Process has opened the door to the creation of a harmonized regional higher education space which was supposed to make European higher education more competitive and attractive, specifically to US higher education (Kehm 2010). The internationalization became the focus of higher education development. Therefore, the international recognition of the universities, their role in international academic mobility attracted more than ever the attention of policy-makers.

This analysis shows that almost in all cases the rationale behind such initiatives was in the state economic, political and social objectives. The "natural" development of universities was not the source of the policy changes.

\section{Design of Excellence-Driven Policies and Initiatives}

The question of the design of excellence initiatives has a number of elements:

- Does the initiative support the development of universities as an entity or certain individual units (departments)?

- Does it encourage mergers and acquisitions?

- What is its scale in terms of money and time?

- How are the universities being selected?

- What are the universities expected to do? What do they suggest to do?

It was found that the largest excellence initiatives were focused on the universities as a whole. There are two explanations that could be drawn from the interviews: (a) international rankings consider whole universities; (b) such design allows all resources of the university to be involved in its development.

It could be claimed that mergers were not the most important part of any of these initiatives. Exceptions are France, Denmark and China - countries which relied significantly on the merger mechanism (Salmi 2009). Also, Russian "Federal universities project", which was to establish a big regional or macro-regional 
university through merging existing ones (Froumin and Povalko 2014), illustrates how mergers and acquisitions could be used to implement excellence policy.

Nevertheless, the reason not to use mergers widely proved to be simplemergers take time; their first stage is very risky, because of disorganization and loss of priorities as shown, for example, from the research on mergers in Finland done by Ursin et al. (2010).

Such famous mergers that have created Manchester University, Aalto University and Strasbourg University happened with the same objective, but outside of the excellence initiatives.

The question of phasing and timing of excellence initiatives is also an important part of policy design. It should be stressed that the number of launched programs and the phasing of excellence initiatives are different from country to country. There was a single excellence program in Australia, Finland, Spain, Norway, for example. In Germany, South Korea, Taiwan multi-phase programs have been implemented, alternatively. The duration of each initiative (or phase) ranges from 3 to 7 years in most cases (Salmi and Froumin 2013).

Most countries adopted open competition as a mechanism to select particular universities which would achieve global competitiveness. Competitive selection is usually based on the previous records of the universities and their development plans. German government evaluated 137 proposals submitted by graduate schools and clusters of excellence, for example Salmi and Froumin (2013). The exceptions to this are China and Taiwan. China picked universities for the project 985 after the review of their performance and potential in a directive way. Taiwan government did the same taking current university-industry cooperation as the key selection criteria.

It is important to mention that in all cases the evaluation of these proposals involved international experts. For many countries, such involvement was the first step to the real internationalization of expert decision-making in higher education. Russian government has decided to include leaders of a number of foreign universities from Top 100 of Shanghai ranking into the selection committee. This selection committee was praised by the government and universities for the quality and transparency of its work. As a result, all members of the selection committee were asked to stay as the members of the Project Implementation Oversight Committee which was to monitor the implementation of strategic plans regularly.

The most interesting question of this part of the paper is what universities put in their plans? The answer is very straightforward - they put there the actions that directly or indirectly lead to the improvement of performance indicators used in world university rankings.

Simple calculations on performance indicators used by rankings show that research and publication activities worth nearly two thirds of the overall ranking score on the average. Indexes related to quality of the education worth $20 \%$. International presence comes out slightly more than $5 \%$ in world university rankings. The universities and the ministries respond to this by making the development of improvement plans mainly research oriented. The quality of the education itself, as well as the international component in terms of students and faculty remains on the periphery (Salmi and Froumin 2013). 
The study has found that in most cases the design of the universities' plans is based on clear indicators of universities performance. Much emphasis is on the idea that the aim of "pushing" universities for excellence is not only to achieve specific indicators, but to develop within-the-university culture of self-development and change management. However, the majority of the plans do not have specific elements of the design to achieve this goal.

Indeed, when governments start to push higher education institutions for excellence they make demands and requirements for universities' performance and activities. Considering that world university rankings constitute most frequently used complex indicators for conducting excellence-driven policy implementation (Salmi 2009), governments are guided (sometimes blindly) by rankings parameters. The indicators of the global rankings are used to develop and plan not just the outcomes, but the process as well.

Under the influence of rankings, governments make their direct requests for universities' productivity. At the same time, universities introduce their internal performance criteria to be highly ranked in the future. Cumulatively, it leads to the fact that selected universities change the content of their work significantly. The practice shows that in certain circumstances they do it for the worse, but not for the better.

As can be seen from above, on one hand the design of excellence policies fosters positive competition in higher education system; it also triggers the development of research activities. On the other hand, the policy design based on rankings indexes "governs how university administrators shape the policy and direction of institutions themselves in a bid to rise up the rank" (Barber et al. 2013, p. 20). Moreover, there are examples relating to different countries when the design of such initiatives leads to destructive change of emphasis of universities which participate in excellence programs.

When the design of excellence policy is developed and universities start to function according to new circumstances, governments need to support program implementation by monitoring preliminary results to timely adjust it for changing conditions. Also, each government needs to evaluate outcomes of the program it has introduced. These two questions of implementation and outcomes assessment of excellence-driven policies and initiatives are to be discussed in the next part of the paper.

\section{Implementation and Outcomes of Excellence-Driven Policies and Initiatives}

When considering the implementation mechanisms of excellence-driven policies and initiatives, a surprising fact was found-participating universities that are supposed to be the leaders of higher education system got more restrictions on their autonomy than other ("normal") universities. This is a very key characteristic of the implementation approach used by the governments. The allocation of big money 
makes the governments worry about its efficient use. To ensure this efficiency and effectiveness, governments build complicated instruments to control the universities. For many centuries, the autonomy and internal energy of universities were the main sources of higher education development. The excellence initiatives represent different approaches where the push for the excellence comes from outside, from above the universities. The challenge for the governments is to find the right push instruments to ensure flexibility and internal motivation of participating universities.

The following questions were considered to elaborate on the governments approaches to develop specific implementation instruments:

- Who is in charge? What is the role of the government or the Ministry of Higher Education/Education on the implementation of excellence-driven policies and initiatives?

- How do governments allocate money? What is the degree of freedom?

- How do central authorities monitor results? How do they measure the effectiveness of policy implementation? How do they evaluate the progress?

- Do the authorities intervene and how?

In all the cases, the Ministries of Education (and Science or Higher Education) are in charge of the implementation process. Mainly, they partner with a national higher education or research funding agency. They usually delegate the function of day-to-day operation support to designated a program implementation agency (PIA). The role of such agency is to interpret the Ministry's policies, collect data, provide logistical support for the expert evaluation, and ensure the communication among the universities and between the Ministry and universities. In all the cases, these agencies were involved (even through the monitoring) into internal business of universities. It consequently manifests new modality of the relationships between the universities and the government.

In most cases, such agencies adopt business approaches when the program is being implemented. They use key performance indicators (KPI) to evaluate universities' progress, and encourage universities to hire consultancy companies to build effective management structure. The Russian agency hired a consulting company to teach universities how to use project management in their operation. These details confirm that the excellence initiatives are linked with the economic mobilization of the higher education systems under New Public Management frameworks (Bleiklie 1988; Stech 2011).

In some cases, such agency reports not to the Ministry unit that is responsible for higher education policy, but to some special project units. It means that the implementation of the excellence initiative is becoming a separate stream within the higher education policy implementation. In a number of countries such as Germany or Russia, program implementation agencies serve as technical support organizations carrying out selection or monitoring procedures. Furthermore, PIA exerts significant impact on resource allocation. Relying on decisions made by agency experts, Ministries grant, extend or cut off funding. 
In the majority of the initiatives, the governments allocate special development grants to the participating universities which often mean that universities can only spend this grant for specific type of expenses. What is more, some governments, such as Canada in 2014 for example, set research and development priorities in a top-bottom way based on their own views when allocating money.

The accuracy of the spending is being carefully monitored by the governments of project implementation agencies. Interviews conducted during the research suggest that the intervention of the Ministry of Finance (or equal agency) is a quite common feature of the implementation process. This is another manifestation of the limits of the university autonomy imposed by the excellence policies.

According to Salmi's (2009) calculation on resource allocation per university by excellence initiative, the amount of money provided for universities differs significantly from country to country. While, Australia infused from $\$ 1$ million to $\$ 4$ million to each Centre of Excellence in (2003), Chinese government has devoted nearly $\$ 300$ million to Peking University and Tsinghua University in 1999. France has provided its "Operational Campus" with nearly \$620 million in 2008.

It should be emphasized that monitoring of the implementation, as well as the monitoring of the results of the program is a difficult task. First, the implementation agency should find the right balance when increasing bureaucratic pressure on universities asking them for regular reporting; second, the time of such projects is too short to see the final fruits of the intervention. It means that the monitoring system inevitably uses short-term indicators to evaluate the progress.

In many countries, the academics complain that the implementation agencies or the ministries are pressing the universities for more reports (Hazelkorn 2011). Almost in all cases, the monitoring systems include annual or even semi-annual scanning of the changes in universities' characteristics and criteria used by the international rankings. Therefore, universities feel constant pressure to publish more and in better journals, to attract more international students and research contracts.

Even more, there is almost no outcome, but mostly process indicators and parameters (like number of international students) are being used to evaluate excellence policies. In Russia such indicators include number of joint programs, number of international researchers hired by universities (Froumin and Povalko 2014).

Thus, the monitoring systems are becoming an instrument of influencing internal policies of universities. As it was shown above, almost all excellence initiatives imply the development of the strategic plan (program, action plan) by the participating universities. The PIA follows the implementation of these plans through the reporting and monitoring systems. These strategic plans or "roadmaps" are usually based on specific activities or strategic projects. The example of the Russian Federation illustrates the significance of such "roadmaps" not so much for universities, as for program implementation agencies. Fifteen Russian universities were asked to develop and present their roadmaps before the PIA. One university out of the whole group was expelled from the excellence program by the reason of unsatisfactory "roadmap". 
Criteria used to assess universities claiming for excellence serve as formal guidelines in many cases. Moreover, it is proved by the practice that universities reorganize their activity to comply with the criteria. However, their real performance quality could remain the same or, what is more, decline.

Several universities participating in excellence-driven programs were examined in the research. The analysis has shown that in a year or two many activities carried out by these universities become bureaucratized. Formal performance indicators imposed by international rankings such as the number of publications or the ratio of foreign students lead to the fact that higher education institutions introduce cumbersome systems of internal control to become top rated. To achieve their goals which are sometimes too ambitious, university administrators build a hierarchy to control the performance of each organizational unit or even each research or teaching employee. Our respondents complained that reporting back is sometimes more time consuming than doing their primary job. All the countries without exception use international review as an important instrument for the evaluation of progress. The Ministries recommend universities to create their own international expert panels to review the progress.

The discussion about the outcomes of the excellence initiatives is limited by the data available. There are three types of outcomes that are usually discussed in the literature and in the governments' reports: the changes in the ranking position of participating universities; the changes in other indicators used by the ministries within the monitoring of the initiatives; internal changes at the universities. It could be argued that the changes in higher education system as a whole should be considered as an outcome of excellence-driven policy or initiative. However, the analysis of the changes in the ranking positions does not show sustainable impact of such policies and initiatives (Table 2).

National reports on the excellence initiatives provide the information about other changes in productivity and quality of the participating universities. They report about increase in the quality of incoming students, about new facilities (mainly research facilities) and more international partnerships (Hazelkorn 2007; Salmi and Froumin 2013).

The interviews also show significant innovations in the management structure and management processes at the participating universities. They include: new incentives for the professors and researchers, interdisciplinary research centres and graduate programs. Units that are dealing with international publications, PR, and links with the industry have increased in scale and quality. In many cases, universities reformed their governance structure giving more power to the committees formed with external (international) experts. Many of these changes reflected the move of the university management to business model. Unfortunately, at some instances this business-type behaviour leads to questionable practices.

There are interesting examples when universities "go the vole" to comply with rankings criteria. Adventurous universities offer huge amounts of money to highly cited and internationally recognized scholars to change their affiliation. There are examples which boggle the mind when universities pay to journals indexed by Scopus or Web of Science for publication of the papers. 
Table 2 Universities in TOP 100 of world university rankings

\begin{tabular}{l|l|l|l|l|l|l|l|l|l}
\hline \multirow{2}{*}{ No } & Country & 2008 & \multicolumn{2}{l}{2011} & \multicolumn{2}{l|}{2014} & \\
\cline { 3 - 11 } & & ARWU & QS/THE & ARWU & QS & THE & ARWU & QS & THE \\
\hline 1 & United States & 54 & 38 & 53 & 31 & 51 & 52 & 28 & 45 \\
\hline 2 & United Kingdom & 11 & 17 & 10 & 19 & 12 & 8 & 19 & 11 \\
\hline 3 & Australia & 3 & 7 & 4 & 8 & 4 & 4 & 8 & 5 \\
\hline 4 & Netherlands & 2 & 4 & 2 & 3 & 4 & 4 & 6 & 6 \\
\hline 5 & Canada & 4 & 4 & 4 & 4 & 5 & 4 & 5 & 4 \\
\hline 6 & Germany & 6 & 3 & 6 & 4 & 4 & 4 & 3 & 6 \\
\hline 7 & Switzerland & 3 & 3 & 4 & 3 & 3 & 5 & 4 & 3 \\
\hline 8 & Japan & 4 & 4 & 5 & 6 & 2 & 3 & 5 & 2 \\
\hline 9 & France & 3 & 2 & 3 & 2 & 3 & 4 & 2 & 2 \\
\hline 10 & Sweden & 4 & 2 & 3 & 2 & 3 & 3 & 2 & 3 \\
\hline 11 & China & 0 & 2 & 0 & 2 & 2 & 0 & 3 & 2 \\
\hline 12 & Russia & 1 & 0 & 1 & 0 & 0 & 1 & 0 & 0 \\
\hline
\end{tabular}

Academic Rankings of World Universities (2014), QS World University Ranking (2014), The World University Rankings-Times Higher Education (2014)

These findings make it reasonable to summarize this part of the paper arguing that the design of excellence-driven policies and initiatives based on clear formal indicators provides universities with the "guiding stars". It is clear for universities what should be done to perform well in terms of the excellence programs. But the question of how it should be done remains open and by no means all universities answer it for the real benefit of their development. Usually, the changes in ranking position are considered as the main outcome of success or failure for the university, as well as the state. An even more challenging issue is the real impact of excellence-driven policies on universities and on overall higher education systems in general-particularly in the context of Bologna Process.

\section{Conclusion: Excellence-Driven Policies, Higher Education Policies and Bologna Process}

The excellence-driven policies and initiatives are becoming an important part of the state higher education policies around the globe. They reflect new tendencies of competing states that mobilize and push higher education institutions for the changes to achieve globally recognized excellence. It would be too easy to blame governments for the excessive control, for constraints on the university autonomy. The states pursue their legitimate objectives, while the universities look slow for them. That is why excellence-driven policy is a clear manifestation of New Public Management policy in relation to higher education. 
This set of policies inevitably interacts with the Bologna process. There are both synergy and contradiction in this interaction.

The synergy side relates to internationalization. Both policies consider the internationalization as a key process and objective. The aspiration to have more international students obviously corresponds with the Bologna Process priority of mobility. Such aspiration requires the creation of the favourable conditions for the international academic mobility. More and more universities introduce ECTS and Diploma Supplement in their attempts to attract international students. Creation of joint (international) programs is also the part of the excellence-driven policies. This also goes well with ECTS, comparable standards, mobility.

Partially, the synergy between the excellence-driven policies and Bologna Process appears in the common attention to the quality control. However it is possible to disagree with Stech (2011) who argues that the Bologna Process is another manifestation of the NPM because it has a number of elements that are in contradiction with the excellence-driven policies which indeed reflect the ideology of NPM.

The main contradiction between Bologna Process and excellence-driven policies lies in the difference between the target groups and the time frame. While Bologna Process is aimed at evolutionary modernization of the system as a whole, the excellence initiatives focus on a selected group of universities within relatively short timeframe. It can create risks of moving public funds to the very elite groups of universities. What is probably even more important, the expansion of excellence-driven initiatives can create an expansion of the direct involvement of the government into the operations of the universities. The temptation to use short and simple list of key performance indicators could be too strong. Indeed, if the government "successfully" manages the leading universities, it has good rationale to manage directly other universities as well.

At the same time, it should be admitted that the excellence-initiatives proved their impact on universities. The impressive pace of the positive changes at the universities participating in such programs is their significant result. Therefore, the challenge for the governments is to continue the push for the excellence while respecting and nurturing the universities autonomy and the culture of self-development at the same time.

Acknowledgments Authors are grateful to Jan Sadlak and Jamil Salmi for the idea of the paper and useful comments, to Phil Altbach, Alexander Povalko, Yaroslav Kouzminov and Irina Karelina for fruitful discussions of the excellence initiatives.

Open Access This chapter is distributed under the terms of the Creative Commons Attribution Noncommercial License, which permits any noncommercial use, distribution, and reproduction in any medium, provided the original author(s) and source are credited. 


\section{References}

Academic Ranking of World Universities. (2014). http://www.shanghairanking.com/. Accessed 17 August 2014.

Altbach, P., \& Salmi, J. (2011). The road to academic excellence: The making of world-class research universities. Washington DC: Directions in Development, The World Bank.

Barber, M., Donnelly, K., \& Rizvi, S. (2013). An avalanche is coming. Higher education and revolution ahead. Institute for Public Policy Research. http://www.pearson.com/avalanche/. Accessed 29 August 2014.

Bleiklie, I. (1988). Justifying the evaluative state: New public management ideals in higher education. European Journal of Education, 33(3), 299-316.

Boli, J., Ramirez, F., \& Meyer, J. (1985). Explaining the origins and expansion of mass education. Comparative education review, 29(2), 145-170.

Bretones, D. (2011). Fostering innovation: The role of French competitiveness poles. Critical analysis for an application in the latin American countries. Journal of Global Business Administration, 3(1), 1-18.

Carnoy, M., Loyalka, P., Dobryakova, M., Dossani, R., Froumin, I., Kuhns, K., \& Rong, W. (2013). University expansion in a changing global economy: Triumph of the BRICs? Stanford: Stanford University Press.

Danish International Research Foundation. (2003). Evaluation of the Danish national research foundation Centres of Excellence. Report of an International Panel.

Ferlie, E., Ashburner, L., Fitzgerald, L., \& Pettigrew, A. (1996). New public management in action. Oxford: Oxford University Press.

Froumin, I., Kouzminov, Y., \& Semyonov, D. (2014). Institutional diversity in Russian higher education: Revolutions and evolution. European Journal of Higher Education, 4(3), 209-234.

Froumin, I., \& Povalko, A. (2014). Top down push for excellence: Lesson from Russia how world-class universities affect global higher education (pp. 47-65). The Netherland: Sense Publ.

Group of Eight. (2014). Group of eight: Australia. Policy Note: International Students in Higher Education and their Role in the Australian Economy. March, 2014.

Hazelkorn, E. (2007). The impact of league tables and rankings systems on higher education decision making. Higher Education Management and Policy, 19(2), 1-24.

Hazelkorn, E. (2011). Globalization and the reputation race in rankings and the reshaping of higher education: The battle for world wide excellence. London: Palgrave MacMillan.

Hood, C. (1991). A public management for all seasons? Public Administration, 69, 3-19.

Kehm, B. (2006). The German initiative for excellence and the issue of ranking. International Higher Education, 44, 20-22.

Kehm, B. (2010). Quality in European higher education: The influence of the Bologna process. Change: The magazine of higher learning. May-June. http://www.changemag.org/Archives/ Back\%20Issues/May-June\%202010/quality-european-full.html. Accessed 19 August 2014.

Lau, A. (2012). Masdar city: A model of urban environmental sustainability. Stanford Undergraduate Research Journal, 11, 77-82.

Meyer, J., \& Rowan, B. (1977). Institutionalized organizations: Formal structure as myth and ceremony. American Journal of Sociology, 83(2), 340-363.

Mohrman, K., Ma, W., \& Baker, D. (2008). The research university in transition: The emerging global model. Higher Education Policy, 21, 5-27.

QS World University Rankings. (2014). http://www.topuniversities.com/university-rankings/ world-university-rankings/. Accessed 17 August 2014.

Sadlak, J. (2011). Ranking in higher education: Its place and impact. Retrieved October 20, 2014 from http://www.educationarena.com/pdf/sample/sample-essay-sadlak.pdf

Sadlak, J., \& Liu, N. C. (2009). "World-Class": Aspirations and reality checks. In J. Sadlak \& N. C. Liu (Eds.), The world-class universities as part of a new higher education paradigm: From 
institutional quality to systemic excellence. Bucharest, Cluj, Shanghai: UNESCO-CEPES, the Cluj University Press, and the Shanghai Jiao Tong University.

Salmi, J. (2009). The challenge of establishing world-class universities. Washington DC: The World Bank. In J. Sadlak \& N. C. Liu (Eds.), The world-class universities as part of a new higher education paradigm: From institutional quality to systemic excellence. Bucharest, Cluj, Shanghai: UNESCO-CEPES, the Cluj University Press, and the Shanghai Jiao Tong University.

Salmi, J. (2012). Attracting talent in a global academic world: How emerging research universities can benefit from brain circulation. Academic Executive Brief, 2(1). http://academicexecutives. elsevier.com/sites/default/files/AEB_2.1_Salmi.pdf. Accessed 25 August 2014.

Salmi, J., \& Froumin, I. (2013). Excellence initiatives to establish world-class universities: Evaluation of recent experiences. Journal of Educational Studies, 1, 25-69.

Stech, S. (2011). The Bologna process as a new public management tool in higher education. Journal of Pedagogy, 2(2), 263-282.

SUDT-MIT. (2014). Singapore University of Design and Technology and Massachusetts Institute of Technology International Design Centre.

The World University Rankings-Times Higher Education. (2014). http://www. timeshighereducation.co.uk/world-university-rankings/. Accessed 17 August 2014.

Ursin, J., Aittola, H., Henderson, C., \& Valimaa, J. (2010). Is education getting lost in university mergers? Tertiary Education and Management, 16(4), 327-340. 